\title{
Political values count but issue ownership decides? How stable and dynamic factors influence party set and vote choice in multiparty systems
}

International Political Science Review 2016, Vol. 37(2) 26I-276 (C) The Author(s) 2014

Reprints and permissions: sagepub.co.uk/journalsPermissions.nav DOI: $10.1177 / 01925$ I2II4558456 ips.sagepub.com (SAGE

\author{
Rune Karlsen \\ Institute for Social Research, Norway
}

\section{Bernt Aardal}

Department of Political Science, University of Oslo, Norway

\begin{abstract}
This article addresses the relationship between latent predispositions and political campaign communication. We propose that political values are decisive in a voter's calculation of which parties she may consider voting for, constituting his or her party set. Furthermore, we argue that the theory of issue ownership contributes to explaining the choice of party within the party set. In addition to investigating salient single issue ownership, we relate issue ownership to parties presenting voters with comprehensive policy packages and study the effect of cumulative issue ownership, that is, issue ownership in several policy areas. We test the hypotheses using data from the Norwegian Election Study of 2009. Our findings support our expectations: stable elements affect which parties are included in the party set, and issue ownership affect the choice between the parties within the set. However, political values also affect the choice between parties in the set. Finally, our data show that cumulative issue ownership has a greater effect than issue ownership of one particularly salient issue. The final section of the article discusses the implications for the theory of issue ownership in general and the model presented in this article in particular.
\end{abstract}

\section{Keywords}

Voting, political values, ideology, party set, consideration set, issue ownership

\section{Introduction}

The increasing volatility and indecisiveness among voters represents a major challenge not only for political parties competing for votes, but also for the analytical tools used to understand the 
processes involved. The influence of political values on vote choice has been acknowledged since the early studies of voting behaviour, emphasizing stable and long-term commitments among citizens (Campbell et al., 1960; Downs, 1957; Inglehart, 1971; Knutsen and Kumlin, 2005; Lipset and Rokkan, 1967). However, since the 1980s numerous studies have shown that the media and campaign communication influence voters as well. Much attention has been given to the theory of issue ownership, which combines long-term factors and the importance of the election campaign: political parties 'own' different issue areas, and try tomake the owned issues salient during campaigns in order to define the criteria for the voters' choice (Petrocik, 1996). Although the issue ownership perspective has received increasing attention, surprisingly few studies have focused on the effect of owned issues for vote choice. ${ }^{1}$

In this article, we address the relationship between political values and political campaign communication in multiparty and multidimensional systems. We propose that political values are decisive in the voter's calculation of which parties she may consider voting for, constituting her party set (Holmberg and Oscarsson, 2004; Oscarsson et al., 1997). ${ }^{2}$ Although we expect that political values matter for the choice between the parties within the set, we believe that a given ideological profile to a large extent leaves the final choice between the parties in the party set open. Moreover, we relate the structuring role of political values to the theory of issue ownership, and highlight the importance of ownership of particularly salient issues for the choice between the parties in the set (Belanger and Meguid, 2008; Petrocik, 1996). In addition to saliency, we introduce the concept of cumulative issue ownership. This concept refers to the scope of ownership: issue ownership of several policy dimensions or areas. We suggest that cumulative issue ownership is as important as saliency when it comes to the choice of parties within the party set. Consequently, we pursue two questions: To what extent and how do political values or predispositions affect which parties the voters include in their party set? And how does issue ownership theory contribute to explaining the choice between the parties within the set?

We investigate these questions and test our hypotheses using data from the Norwegian Election Study of 2009. Our findings largely support our expectations: political values affect which parties are included in the party set, and perceptions of issue ownership affect the choice between the parties in the set. Moreover, political values also affect the choice between parties in the set, but political values are closely related to perceptions of issue ownership. Finally, our data show that cumulative issue ownership, that is issue ownership on several policy dimensions, has a greater effect than ownership of one particularly salient issue.

The article proceeds as follows. In the first section, we present the main argument for how stable political values constitute the foundations of party sets; in the second section, we discuss how the theory of issue ownership can contribute to an understanding of the choice between the parties within the set. The third section addresses the question of data and methods and describes the measurements used in the analysis. The empirical analysis is divided into two parts. Firstly, we study how political values structure party sets, and secondly we investigate the effect of political values and salient and cumulative issue ownership for the choice between the parties in the sets. In the final section, we summarize the findings and discuss their implications for the theory of issue ownership in general and the model presented in this article in particular.

\section{Core political values and party set}

The increasing electoral volatility in modern democracies is related to the erosion of cleavages and the dealignment between parties and voters (e.g. Dalton et al., 1984). Despite disagreements on how and to what extent traditional ties between social structure and voting have weakened, there seems to be a consensus that social indicators do not have the same explanatory power as earlier 
and that political values have a more independent effect on vote choice (Dalton et al., 1984; Franklin et al., 1992; 2009; van der Brug, 2010).

Core political values are normative principles and beliefs about government, citizenship and society that individuals would like to see implemented in the political system (Knutsen and Kumlin, 2005: 125; McCann, 1997). In his seminal study, Converse (1964: 211) referred to political values as the glue that binds together more specific attitudes and beliefs. There is no consensus on the number and content of core political values in modern democracies (Schwartz et al., 2010), and different numbers of core values have been identified by scholars (e.g. Inglehart, 1971; Knutsen, 1995; McCann, 1997). Inglehart (1971), for example, identified a generational shift from materialist to post-materialist values, while Flanagan (1982) argued that the materialist-post-materialist dimension was a mix of two value dimensions, one opposing authoritarian versus libertarian values and the other materialist versus non-materialist values.

The impact of political values is not new. Political ideology was already emphasized in the traditional models of electoral research. In the Michigan model, social background and political values were reflected in voters' party identification (Campbell et al., 1960). In addition, although the Lipset-Rokkan model has been viewed primarily as a socio-structural model, the authors themselves emphasize the need to take subjective perceptions and values into account (Lipset and Rokkan, 1967: 2-3). In this article, we use political value dimensions partly derived from the Lipset and Rokkan cleavage model.

Political values undoubtedly affect vote choice (e.g. Knutsen and Kumlin, 2005), and values are thought of as being stable over time; Zaller (1991) refers to stability as a defining characteristic of political values. For example, analyses of Norwegian data show that political values are highly stable (Aardal, 2011). We propose that although political values are stable, they do not unequivocally point in the direction of only one party, at least not in multiparty systems. Rather, political predispositions define an area of acceptance that defines which parties the voters consider voting for, that is, the voters' party set (Holmberg and Oscarsson, 2004; Oscarsson et al., 1997). This twostep model of vote choice was also suggested by van der Eijk and colleagues in their work on the propensity to vote (van der Eijk, 2002; van der Eijk et al., 2006). Anthony Downs's argument that individuals vote for the party closest to themselves on ideological or issue dimensions arguably also implies that voters might like more than one party (Van der Brug et al., 2007: 11).

The theoretical underpinning of the idea of party set comes from social psychology and social judgement theory (e.g. Sherif and Hovland, 1961). An individual's attitude is conceived to be located in a series of latitudes or zones: the latitude of acceptance, non-commitment and rejection (cf. Oscarsson et al., 1997). From this theoretical perspective, we expect that the ideological predispositions of a voter, that is, his or her political values, will decide which parties will be included in the latitude of acceptance and which parties will be rejected. For example, a voter with proimmigration values is likely to include only parties that are positive towards immigration in her party set and reject parties hostile towards immigration. Within the latitude of acceptance, several parties might be evaluated favourably, although one party might be preferred (Oscarsson et al., 1997). ${ }^{3}$ In this context, we are mostly interested in the parties that are included in the latitude of acceptance and thus constitute the party set. Our first hypothesis is that political ideology is decisive for and structures voters' party sets.

\section{Choice between the parties in the set}

Although we expect political values to be decisive for the structure of party sets, they might also affect the choice between the parties in the set. It is reasonable to expect that issue dimensions other than the ones that are decisive for the party set will contribute to the choice between 
the parties within the set. For example, rightist values on the economic left-right scale might lead voters to include a traditional conservative party as well as a new populist right party, such as the Norwegian Progress Party or the Danish People's Party in the set. However, differences in attitudes towards immigration might nevertheless separate the ones who voted for the conservative party from those who preferred the populist right party. In other words, although two or more parties might be acceptable, one party might 'fit' the ideological profile of the voter better. Consequently, our second hypothesis is that political values, even those that have less effect on the choice of party set, will affect the choice of party within the party set. However, different values might also result in different perceptions of which party has the best policy on issues. We therefore expect political values to be closely related to issue ownership. Hence, our third hypothesis is that the effect of political ideology is closely related to the effect of issue ownership.

In addition to political values, we suggest that campaign factors contribute to the decision between the parties within the set. In recent decades, numerous studies have investigated how political campaign communication can affect voters' behaviour, and the theory of issue ownership has arguably gained increasing popularity (Budge and Farlie, 1983; Petrocik, 1996). The logic is simple: parties 'own' different issue areas. According to Petrocik (1996), it is not sufficient for a party to be associated with an issue to be seen as the issue owner. ${ }^{4}$ The voters must believe in the party's problem-solving ability. Hence, in more recent studies the term 'competence ownership' has been used to distinguish it from so-called associative ownership (e.g. Walgrave et al., 2014). During a campaign, a party tries to make the issues it owns prominent on the media agenda and thus on the voter agenda. A campaign effect occurs when a party succeeds in making its owned issues the focus of the campaign and the criteria that voters use to make their choice (Petrocik, 1996). ${ }^{5}$ For example, in the USA, the Democratic Party is considered better able to reduce unemployment, while the Republican Party is considered better able to keep taxes low. Consequently, the theory predicts that a Democratic presidential candidate will win if unemployment dominates the agenda, while the Republican candidate will win if taxes are voters' major concern.

The issue ownership models make assertions about the macro level and the micro level. At the macro level, the election will be decided by the issues that dominate the agenda. At the micro level voters make their decisions based on which parties voters believe are better able to handle the issue they find most important (cf. Iyengar and Kinder, 1987). Hence, the model consists of two equally important dimensions: ownership and saliency. The combination of ownership and saliency is emphasized both by Petrocik (1996) and by the earlier work of Budge and Farlie (1983). ${ }^{6}$ Recent research also finds that the effect of issue ownership on vote choice is conditioned by the perceived salience of the issue in question (Belanger and Meguid, 2008; Green and Hobolt, 2008). Hence, our fourth hypothesis is that salient issue ownership for one of the parties in the party set will affect the choice between the parties in the set. ${ }^{7}$

In the original formulation of the model, issue ownership was assumed to be stable over time, and was labelled a critical constant from one election to the next. The 'critical' difference between elections was thus the issue priority of the voter (Petrocik, 1996: 826). However, studies of European multiparty systems emphasize that issue ownership might not be as constant as suggested by Petrocik; rather these studies emphasize issue ownership dynamics (Karlsen, 2004; Walgrave et al., 2009, 2014). Issue ownership is most likely less stable in European multiparty and multidimensional systems because a voter might have confidence in the problem-solving ability of more than one party on a given issue. Hence, if a voter has two parties in the party set, she might regard both parties as competent regarding employment issues, for example. Although perceptions of competence are more or less stable, this renders changing issue ownership possible, and parties stand a better chance of challenging issue ownership during campaigns. 
The dynamic aspect of issue ownership has consequences for the micro logic element of the model: the effect of salient issue ownership becomes less clear. If voters believe that more than one party is competent on a particular issue, the effect on voting of making that issue salient is not self-evident.

In addition to salient single issue ownership, which has dominated recent literature, we suggest that the scope of parties' issue ownership - the number of issues that a voter believes a party is best able to handle - is relevant for voters' party choice. Party government is based on parties presenting voters with comprehensive policy packages: policy proposals on a whole range of issues. Hence, the focus on one particularly salient and important issue might be too narrow a perspective. The idea of comprehensive policy packages can be related to the issue ownership perspective. In addition to the micro logic of the issue ownership model, which states that voters will vote for the party they prefer on an issue that is important to them, voters are likely to consider whether parties are competent on a wider range of issues - particularly if those issues are linked to different cleavages or conflict dimensions. Hence, issue ownership on several issue areas, what we designate as cumulative issue ownership, can be considered an alternative to the emphasis on only one important issue. For now, we will propose that the scope of parties' issue ownership - the number of issues a voter believes a party is best able to handle - is relevant for voters' party choice. Hence, in addition to salient single issue ownership, we propose cumulative issue ownership as an important factor affecting voters' choice between parties in the party set: The more issues a voter believes that a party is best able to solve, the more likely she is to choose that party over other parties in her party set. Consequently, the fifth hypothesis is that cumulative issue ownership will affect the choice between parties within the set.

\section{Case, data and method}

Our data is based on the 2009 Norwegian Election Study. Norway is a good case for testing the arguments and hypotheses presented for many reasons. Firstly, it is a parliamentary multiparty system. The political system in Norway is characterized not only by a multiparty structure, but also by a multidimensional cleavage structure. The largest party is the Labor Party (Ap), which constitutes the left on the left-right axis along with the Socialist Left Party (SV). The Conservative Party (H) and the Progress Party (FrP) constitute the right. The so-called centre parties are the Liberal Party (V), the Centre Party (the agrarian party) (Sp) and the Christian Democratic Party (KrF).

Secondly, there has been a huge increase in voter unrest. Although in the 1960s fewer than 25 per cent of voters switched parties from one election to the next, this gradually increased to almost 50 per cent in the 2009 parliamentary election (Aardal, 2011). Accordingly, fewer voters identify with a political party (Berglund, 2004; Dalton and Wattenberg, 2000). Moreover, voters' indecisiveness and fluctuation also have led increasing numbers of voters to postpone deciding. In Norway, the number of voters deciding during the campaign which party to vote for - or even whether to vote at all -has almost quadrupled since the 1960s (Aardal, 2011). ${ }^{8}$

The 2009 Norwegian Election Study is based on a post-election probability sample of 2944 respondents. A net sample of 1782 was obtained, giving a response rate of 61 per cent. The interviews were done face to face, supplemented by telephone interviews with those who were difficult to reach. The 2009 election study includes questions on core political values, party set and issue ownership.

\section{Measurements of political ideology}

We operationalize values with six indexes, each consisting of four to five items. Based on 45 questions, we identified a cluster of six value dimensions using factor analysis (principal component). 
The items with the highest factor loadings then underwent a validity test (Cronbach's alpha), and subsequently five items in four cases and four items in two cases were included in the additive indexes. The first dimension is 'authoritarian-libertarian' comprising questions about the welfare state and immigration. The Cronbach's alpha for this index is .78. The second dimension is publicprivate or left-right comprising questions about state intervention in the economy and economic redistribution. The Cronbach's alpha for this index is .71. The third is a green dimension comprising questions about environmental protection versus economic growth. The Cronbach's alpha for this index is .76. The fourth is a religious-secular dimension including Christian values and ethics. The Cronbach's alpha for the index is .69. The fifth is a global-national dimension including questions on globalization. The Cronbach's alpha for the index is .58. The sixth is (geographical) centre-periphery dimension. The Cronbach's alpha for the index is .63. The items included in the indexes are listed in the online Appendix (available at: http://ips.sagepub.com). Data based on seven election panels shows an average individual stability of 0.6-0.7 (Pearson's $r$ ) for the first four indices. All six value dimensions are important predictors of vote choice in Norway (see Aardal, 2011).

\section{Measurements of party set}

We operationalize party set by combining the standard vote question, 'Which party did you vote for?' with the follow-up question, 'Were there any other party(-ies) you considered voting for?' Consequently, the party the respondent voted for and the parties she considered voting for constitute the party set. This is a rather strict way of measuring party set. A party might be included in a voter's party set and within the area of acceptance without the voter considering voting for the party in this election. However, such strict operationalization will be useful for this article. Using this operationalization, the respondents on average had 1.74 parties in their party set, and 60 per cent of the electorate had a party set consisting of two or more parties. Table 1 reports the proportion of voters that included a party in their party set.

The possible party set combinations are numerous. Based on our knowledge of Norwegian electoral politics, we construct seven party sets each consisting of two parties. The combinations are to some extent based on political proximity, but more important by the exchange patterns of voters between the parties. In addition, we wanted to include every party in at least

Table I. Size of the party set compared to the share of the votes.

\begin{tabular}{lcc}
\hline & $\begin{array}{l}\text { Proportion of voters } \\
\text { including the party } \\
\text { in the set }\end{array}$ & $\begin{array}{l}\text { Share of } \\
\text { the vote }\end{array}$ \\
\hline $\mathrm{R}$ & 3 & 1 \\
$\mathrm{SV}$ & 18 & 8 \\
$\mathrm{Ap}$ & 51 & 35 \\
$\mathrm{Sp}$ & 12 & 7 \\
$\mathrm{KrF}$ & 8 & 5 \\
$\mathrm{~V}$ & 13 & 5 \\
$\mathrm{H}$ & 37 & 20 \\
$\mathrm{FrP}$ & 28 & 19 \\
$\mathrm{~N}$ & 1578 & 1578 \\
\hline
\end{tabular}

Abbreviation of party names. R: Red; SV: Socialist Left Party; Ap: Labor Party; V: Liberal Party; KrF: Christian Peoples Party; Sp: Centre (Agrarian) Party; H: Conservative Party; FrP: Progress Party. 
one set. The two largest parties, the Labor Party and the Conservative Party, are included in many sets. Each set also had to include a reasonable number of respondents. The first party set consists of the Labor Party and the Socialist Left Party. Twelve per cent of the electorate included these parties in their set $(N=1578)$. The second party set consists of the Labor Party and the Centre Party. Five per cent of the electorate included these two parties in the set. The third set consists of the Labor Party and the Conservative Party. Eleven per cent of the electorate included these parties in their party set. The fourth set consists of the Labor Party and the Progress Party. Five per cent of the electorate included these parties in their party set. The fifth set consists of the Conservative Party and the Christian People's Party. Just 2.5 per cent (45 respondents) included these two parties in their set. The sixth set consists of the Conservative Party and the Liberal Party. Five per cent included these parties in the set. The seventh set consists of the Conservative Party and the Progress Party. Fifteen per cent of all voters included these parties in their party set.

\section{Measurements of issue ownership and issue salience}

Issue ownership is operationalized by questions concerning which party the respondent believes has the best policy in a particular issue area. The respondents were asked about their perceptions in nine issue areas: education, taxes, immigration, child and family policy, care for the elderly, environmental protection, regional development, employment and transport and communication. Issue salience was measured with the following open-ended question: Could you mention one or two issues that were important for your voting decision? Eighty-eight per cent of the respondents reported an important issue, and 68 per cent reported an issue that could be connected to any of the nine issue ownership questions.

We measure salient single issue ownership by constructing a variable based on the first issue mentioned. If the respondent has indicated that the party has the best policy on the first issue mentioned, the respondent is coded high on the salient-ownership variable.

In order to measure cumulative issue ownership we add the number of issues for which each respondent indicates that the party has the best policy. Hence, the variable ranges from zero to nine. To investigate the effect of cumulative ownership on the choice between parties in the party set, we construct a variable where we subtract cumulative ownership for one of the parties from with cumulative ownership for the other party in the pairwise party set used in the analysis.

\section{Analysis}

The empirical analysis has two sections linked to the two research questions formulated earlier. Firstly, we investigate the relationship between political ideology and party sets. Secondly, we study to what extent ideology and issue ownership affect the choice between parties in the set.

\section{The relationship between political ideology and party sets}

We argued above that political values are decisive in voters' calculations of which parties they consider voting for. Although earlier studies have shown that political values affect vote choice, we propose that stable values in multiparty systems do not unequivocally point in the direction of only one party but define acceptable parties, that is, those an individual might consider voting for. Hence, the hypothesis is that political values are decisive for and structure voters' party sets. Table 2 reports the effect of political values for the inclusion of parties in the party set. As mentioned in the method section, we investigate seven party sets. 


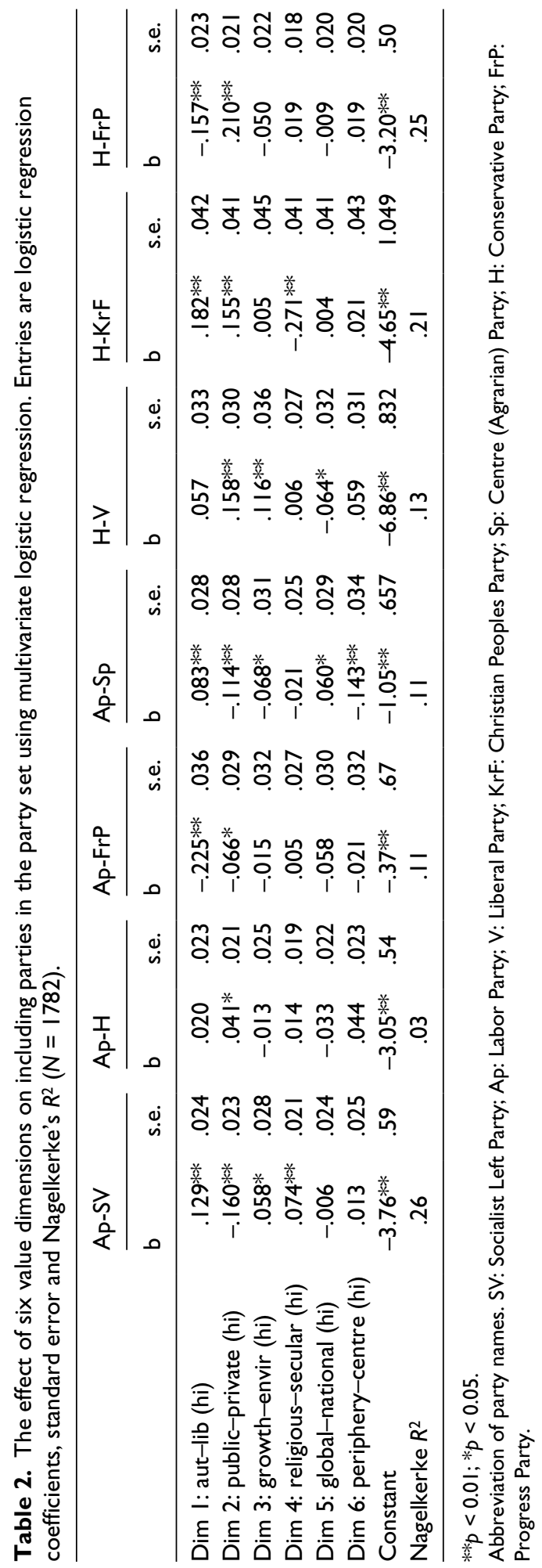




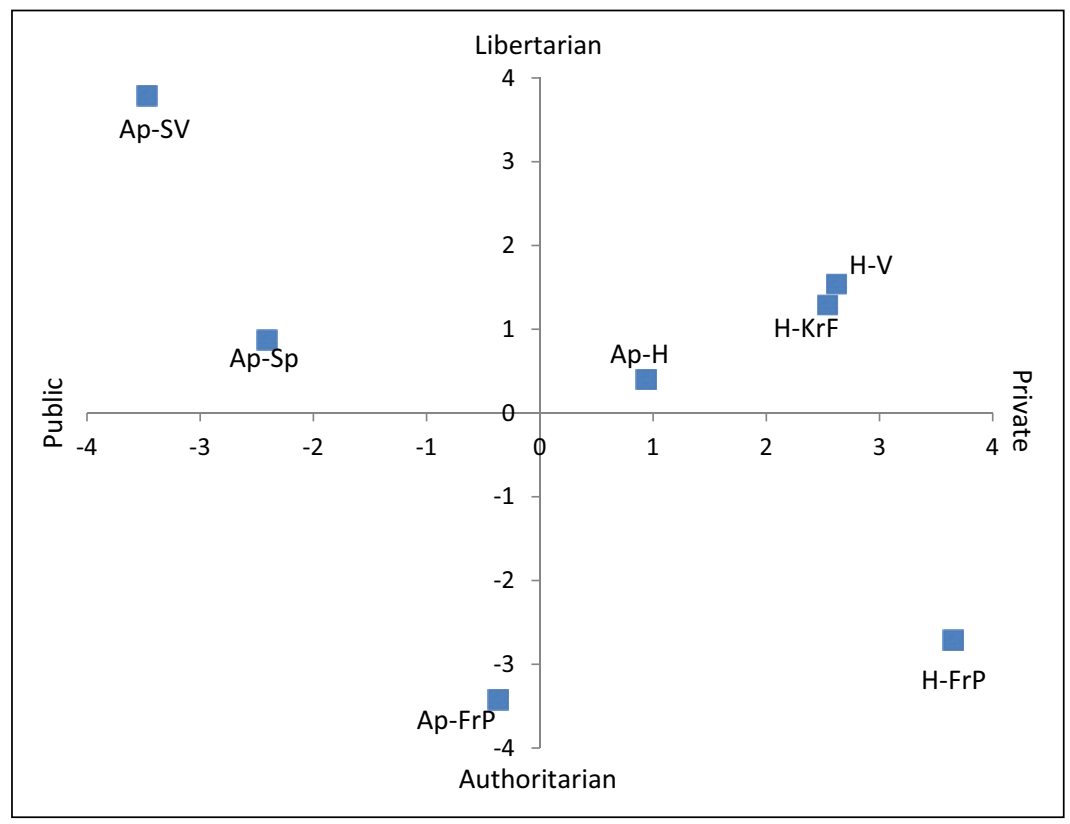

Figure I. The seven party sets in a two-dimensional space. Public-private and libertarian-authoritarian dimensions.

Abbreviation of party names: SV = Socialist Left Party; Ap = Labor Party; V = Liberal Party; KrF = Christian Peoples Party; $\mathrm{SP}=$ Centre (Agrarian) Party; $\mathrm{H}=$ Conservative Party; FrP = Progress Party.

The results show that political values affect the inclusion of parties in the party set, but that there are differences in this regard among sets. The public-private (left-right) dimension and the authoritarian-libertarian dimension are important for five of the party sets. For example, liberal and leftleaning voters were more likely to include Ap and SV in their sets. These two dimensions are also important for the party set consisting of the Conservative Party and the Progress Party, but with opposite signs. Voters who have authoritarian values and are rightist in their views on the economy are likely to include these two parties in their set. Authoritarian values and to some extent leftist values affect why voters include the Labor Party and the Progress Party in their set.

At first glance, it appears that ideology does not affect why voters had a set consisting of the Labor Party and the Conservative Party. However, we can assume that the voters who include these two parties in their set are less extreme on the public-private dimension than Labor voters who include SV in their party set and Conservative voters who do not include the Labor Party in theirs. This means that other voter groups have more "extreme" values on the independent variables, and an effect analysis similar to the one presented in Table 2 will find little or no effect. This is also suggested by the different levels of explained variance (Nagelkerke's R2), that is how much of the variation in the dependent variable that is explained by the independent variables. The party sets that include parties that together constitute the extreme on one value dimension, Ap-SV (public/ left), H-KrF (Christian values) and H-FrP (private/right, authoritarian), get the higher explained variance. However, if we choose another approach the importance of values is apparent for why voters include the Labor Party and the Conservative Party in their set. In Figures 1 and 2, we show the party sets located in a two-dimensional space. In Figure 1 the horizontal axis represents the mean for the whole electorate on the public-private dimension, while the vertical axis represents the mean on the authoritarian axis. 


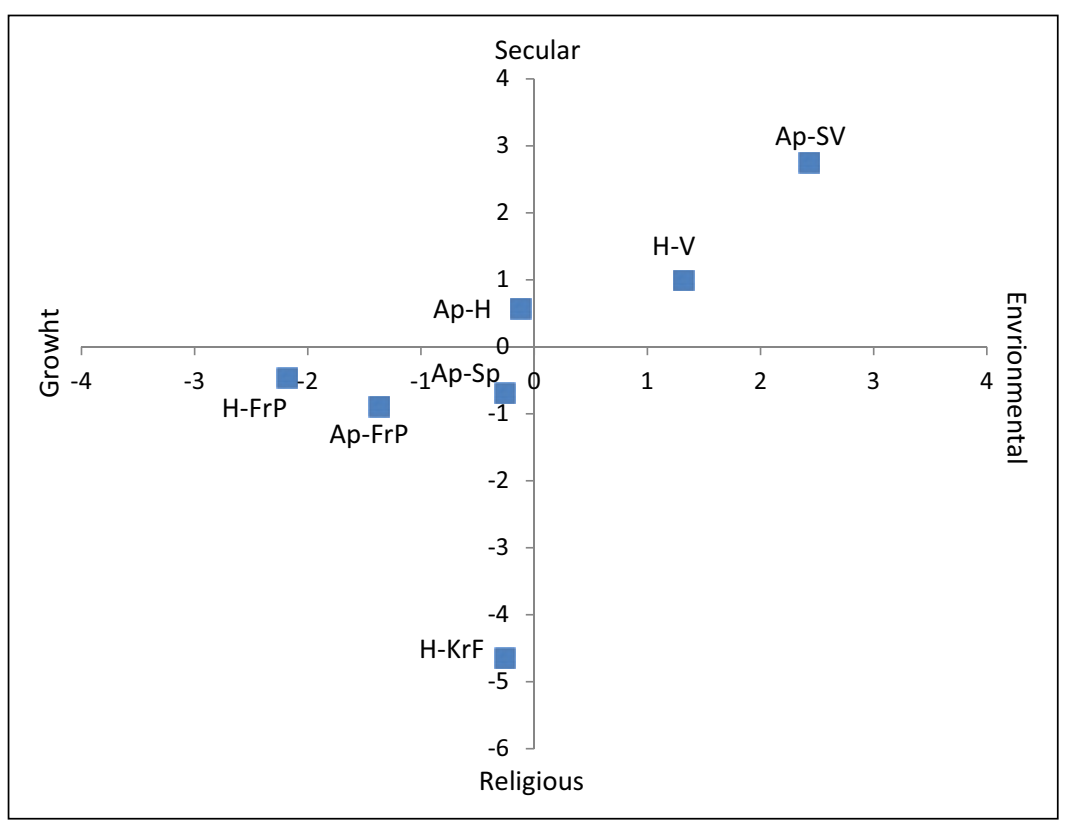

Figure 2. The seven party sets in a two-dimensional space. Secular-religious and growth-environmental protection dimensions.

Abbreviation of party names: SV = Socialist Left Party; Ap = Labor Party; $V=$ Liberal Party; KrF = Christian Peoples Party; $\mathrm{Sp}=$ Centre (Agrarian) Party; $\mathrm{H}=$ Conservative Party; FrP = Progress Party.

Figure 1 clearly shows how political values structure party set consideration. As expected from the analysis presented in Table 2, voters who included the Labor Party and the Socialist Left Party in their set were to the left on the public-private dimension, and libertarian on the authoritarianlibertarian dimension. However, although voters who included the Labor Party and the Progress Party in their set are characterized by authoritarian attitudes, they were located towards the mean on the public-private dimension. The voters who included the Conservative Party and the Progress Party are characterized by authoritarian and private attitudes. The voters who included the Labor Party and the Conservative Party were close to the mean on both dimensions. Hence, political values structure the party sets: the voters who considered voting for the Labor Party and the Conservative Party clearly deviate from those who considered voting for the Socialist Left Party and the Labor Party as well as from those who considered voting for the Labor Party and the Centre Party. They also deviate from the ones who included the Labor Party and the Progress Party, and the Conservative Party and the Progress Party, in the set.

In Figure 2, the horizontal axis represents the mean for the whole electorate on the growthenvironmental protection dimension, while the vertical axis represents the mean on the secularreligious dimension. These results also contribute to our understanding of how ideology structures party choice. As expected from Table 2, the voters who considered voting for the Conservative Party and the Christian Democratic Party had more religion-oriented values and the voters who considered voting for the Conservative Party and the Liberal Party were more environmentally oriented, while the voters who considered the Conservative Party and the Progress Party were more growth oriented. The voters who considered the Labor and the Socialist Left parties were more environmentally oriented and secular than voters who considered the Labor Party and another party. 
Table 3. Effect of political ideology, salient issue ownership and cumulative issue ownership on choice between parties within the set using logistic regression. Pairwise party set: Labor Party (Ap) and Socialist Left Party (SV). Entries are logistic regression coefficients, standard error and Nagelkerke's $R^{2}(N=178)$.

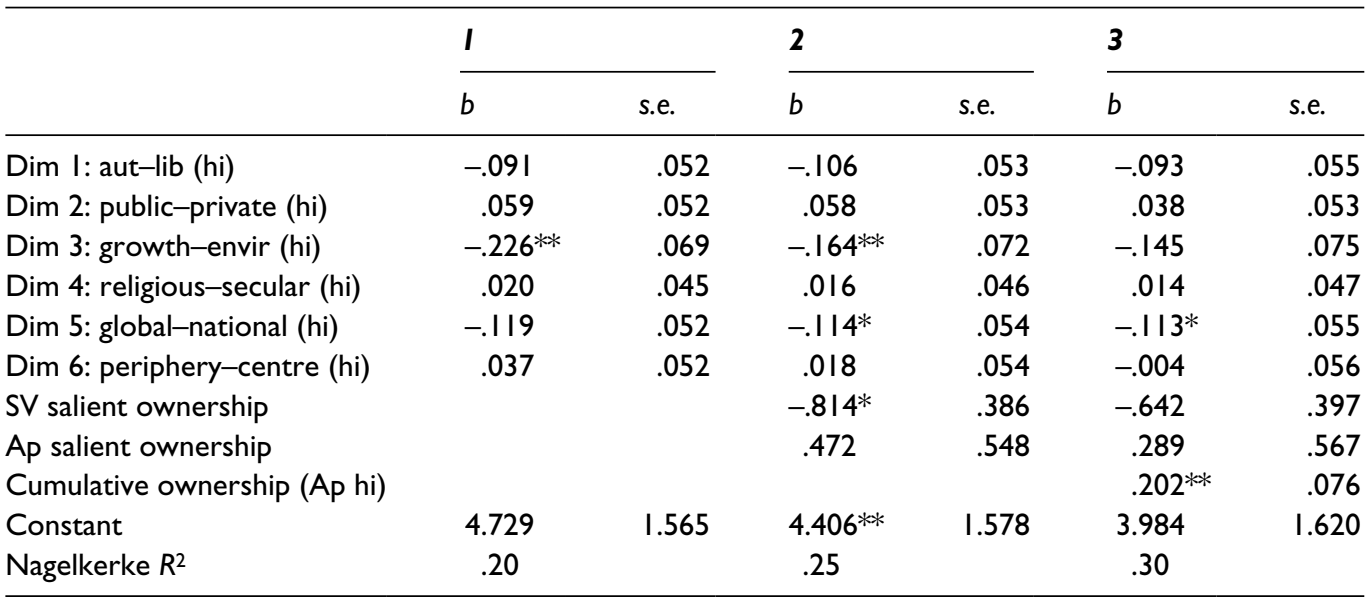

$* * p<0.01 ; * p<0.05$.

Dependent variable (voted for $A p=I, S V=0$ ).

Salient ownership: the respondent has indicated that the party has the best policy on an issue that was important to her vote choice.

Cumulative issue ownership: 'Number of issues Ap has the best policy - the number of issues SV has the best policy'.

\section{Ideology and issue ownership and the choice between parties within the party set}

Although political values structure the voters' party sets, values can also influence the decision between parties in the set. We have discussed how such values might be closely linked to voters' perceptions of the party with the best policy on different issues, and we formulated four hypotheses. We expected political values to affect the choice between the parties in the set (2), and that the effect is closely related to issue ownership (3). We also expected salient issue ownership (4) and cumulative issue ownership (5) to affect the choice between the parties in the set.

To test these hypotheses, we use four of the pairwise party sets accounted for. We exclude from the analysis voters who included a third party in their set. We thus analyse voters who voted for one of the parties and who also considered voting for the other party. We first study the voters who voted for or considered voting for the Labor Party and the Socialist Left Party. The first block consists of the political ideology dimensions, the salient issue ownership is introduced in the second block and cumulative issue ownership is introduced in the third block.

The result of this analysis supports the hypothesis formulated initially. Political values have an effect on the choice within the party set, as pro-environmental values makes it less likely that voters will choose the Labor Party and more likely they will choose the Socialist Left Party. Ownership of a salient issue and cumulative issue ownership has an effect on the vote, but the former has significantly less impact than the latter. Moreover, as expected, the effect of ideology is closely related to issue ownership and is no longer significant when cumulative ownership is controlled for.

Basically the same picture emerges from the analysis of the Labor Party and the Progress Party set presented in Table 3. The public-private dimension has a clear effect on the choice, those who had private-oriented values were less inclined to choose the Labor Party and more inclined to choose the Progress Party. Issue ownership of a salient issue has an effect for the Progress Party, 
Table 4. Effect of political ideology, salient issue ownership and cumulative issue ownership on choice between parties within the set using logistic regression. Pairwise party set: Labor (Ap) and Progress Party (FrP). Entries are logistic regression coefficients, standard error and Nagelkerke's $R^{2}(N=78)$.

\begin{tabular}{|c|c|c|c|c|c|c|}
\hline & \multicolumn{2}{|l|}{$I$} & \multicolumn{2}{|l|}{2} & \multicolumn{2}{|l|}{3} \\
\hline & $b$ & s.e. & $b$ & s.e. & $b$ & s.e. \\
\hline Dim I: aut-lib (hi) & -.119 & .093 & -.122 & .094 & $-.258^{*}$ & .124 \\
\hline Dim 2: public-private (hi) & $-.23 I^{* *}$ & .081 & $-.226 *$ & .087 & $-.248^{*}$ & .109 \\
\hline Dim 3: growth-envir (hi) & -.076 & .077 & -.084 & .093 & -.094 & .103 \\
\hline Dim 4: religious-secular (hi) & .087 & .062 & .064 & .070 & .103 & .076 \\
\hline Dim 5: global-national (hi) & -.045 & .067 & -.054 & .069 & -.127 & .092 \\
\hline Dim 6: periphery-centre (hi) & -.081 & .071 & -.060 & .075 & .041 & .089 \\
\hline FrP salient ownership & & & $-|.88| *$ & .744 & $-1.694 *$ & .851 \\
\hline Ap salient ownership & & & -.631 & .745 & -1.615 & .925 \\
\hline Cumulative issue ownership & & & & & $.608 * *$ & .187 \\
\hline Constant & 3.062 & 1.545 & $3.883^{*}$ & $\mathrm{I} .807$ & 3.272 & 2.225 \\
\hline Nagelkerke $R^{2}$ & .21 & & .32 & & .53 & \\
\hline
\end{tabular}

$*_{p} p<0.01 ; * p<0.05$.

Dependent variable (voted for $\mathrm{Ap}=\mathrm{I}, \mathrm{FrP}=0$ ).

Cumulative issue ownership: $A p=$ positive.

but not for the Labor Party. The effect of political values holds even when we control for salient single as well as cumulative issue ownership. However, cumulative issue ownership increases the explained variance significantly.

The same pattern as in the first two analyses is found in Table 4. Political values have an effect for the choice between the Labor Party and the Conservative Party, as private/right-oriented voters and voters with authoritarian values are less likely to vote for the Labor Party. The effect of the publicprivate dimension holds when we control for issue ownership of a salient issue. Again, cumulative issue ownership reduces the effect of political values, indicating that values have an indirect effect via ownership. Cumulative issue ownership increases the explained variance significantly.

The analysis of the Conservative Party and the Progress Party set reported in Table 6 shows much the same pattern as the three first analyses. Voters who are hostile towards immigration are less likely to choose the Conservative Party, but the effect of ideology is no longer significant when ownership of a salient issue is introduced in the model. Here, Conservative and Progress ownership is significant at the 5-per-cent level. Cumulative issue ownership reduces the effect of ownership of a single salient issue and increases the explained variance considerably.

Overall, the analyses in this section support the four hypotheses (2-5). Political values affect the choice between two parties in a party set; however, ideology is closely related to issue ownership, as the effect is reduced when singular and cumulative issue ownership are controlled for. Singular and cumulative issue ownership affect the choice between the two parties in the set; however, cumulative ownership clearly has a greater effect. In the last section, we discuss the implications of the empirical results for the model suggested in this article in particular and the theory of issue ownership in general.

\section{Discussion and conclusion}

We have argued that core political values are decisive in a voter's calculation of which parties she may consider voting for, and that ownership of a singular salient issue and cumulative issue 
Table 5. Effect of political ideology, salient issue ownership and cumulative issue ownership on choice between parties within the set using logistic regression. Pairwise party set: Labor (Ap) and the Conservative Party $(\mathrm{H})$. Entries are logistic regression coefficients, standard error and Nagelkerke's $R^{2}$ $(N=157)$.

\begin{tabular}{|c|c|c|c|c|c|c|}
\hline & \multicolumn{2}{|l|}{1} & \multicolumn{2}{|l|}{2} & \multicolumn{2}{|l|}{3} \\
\hline & $b$ & s.e. & $b$ & s.e. & $b$ & s.e. \\
\hline Dim I: aut-lib (hi) & $-.111 *$ & .053 & -.077 & .056 & -.110 & .064 \\
\hline Dim 2: public-private (hi) & $-.105^{*}$ & .046 & $-.118^{*}$ & .050 & -.050 & .055 \\
\hline Dim 3: growth-envir (hi) & .076 & .056 & .062 & .060 & .068 & .066 \\
\hline Dim 4: religious-secular (hi) & .023 & .044 & .025 & .045 & .010 & .048 \\
\hline Dim 5: global-national (hi) & -.032 & .049 & -.024 & .052 & -.051 & .056 \\
\hline Dim 6: periphery-centre (hi) & -.040 & .052 & -.027 & .056 & .006 & .062 \\
\hline Cons. salient ownership & & & $-1.935^{* *}$ & .593 & $-1.598 *$ & .623 \\
\hline Ap salient ownership & & & .653 & .477 & .243 & .515 \\
\hline Cumulative issue ownership (Ap) & & & & & $.343 * *$ & .083 \\
\hline Constant & $\mathrm{I} .353$ & 1.268 & 1.375 & 1.369 & .387 & 1.484 \\
\hline Nagelkerke $R^{2}$ & .09 & & .24 & & .38 & \\
\hline
\end{tabular}

$*^{*} p<0.01 ; * p<0.05$.

Dependent variable (voted for $A p=1$, Cons. $=0$ ).

Table 6. Effect of political ideology, salient issue ownership and cumulative issue ownership on choice between parties within the set using logistic regression. Pairwise party set: the Conservative Party $(\mathrm{H})$ and the Progress Party (FrP). Entries are logistic regression coefficients, standard error and Nagelkerke's $R^{2}$ $(N=223)$.

\begin{tabular}{|c|c|c|c|c|c|c|}
\hline & \multicolumn{2}{|l|}{ I } & \multicolumn{2}{|l|}{2} & \multicolumn{2}{|l|}{3} \\
\hline & $b$ & s.e. & $b$ & s.e. & $b$ & s.e. \\
\hline Dim I: aut-lib (hi) & $.147^{* *}$ & .053 & .095 & .057 & .050 & .060 \\
\hline Dim 2: public-private (hi) & .018 & .044 & -.012 & .047 & -.036 & .050 \\
\hline Dim 3: growth-envir (hi) & .067 & .042 & .068 & .044 & .076 & .047 \\
\hline Dim 4: religious-secular (hi) & -.047 & .034 & -.055 & .036 & -.062 & .039 \\
\hline Dim 5: global-national (hi) & -.056 & .040 & -.054 & .043 & -.050 & .046 \\
\hline Dim 6: periphery-centre (hi) & .047 & .037 & .053 & .039 & .018 & .043 \\
\hline FrP salient ownership & & & $-1.082 * *$ & .384 & $-.978 *$ & .412 \\
\hline Cons. salient ownership & & & $1.023^{*}$ & .415 & .517 & .444 \\
\hline Cumulative issue ownership & & & & & $.311 * *$ & .068 \\
\hline Constant & $-1.64 \mid$ & 1.018 & -.840 & 1.101 & -.315 & 1.193 \\
\hline Nagelkerke $R^{2}$ & .12 & & .24 & & .36 & \\
\hline
\end{tabular}

$*_{*}<0.01 ; * p<0.05$.

Dependent variable (voted for Cons. $=\mathrm{I}$, Progress $=0$ ).

ownership contribute to the choice between the considered parties. The results of the empirical analysis support this argument, along with some essential modifications.

Our first hypothesis states that ideology would be decisive for and structure the voter's party sets. Our results indicate that this indeed is the case. However, the multivariate logistic regression 
analyses showed only modest effects for the set consisting of the Labor Party and the Conservative Party. Voters who consider both parties are not extreme on any value dimension. Hence, the influence of political values does not show up in an effect analysis. In contrast, the importance of values was evident when we studied the different party sets in two-dimensional ideology spaces. Voters who included the Labor Party and the Conservative Party in their set were not extreme on any dimensions; instead, these voters constituted the centre on all dimensions. Since these voters do not have strong attitudes on the most important policy dimension separating these two parties, they are able to include both in their party set. In this sense, political values structure electoral choices by reducing the number of alternatives.

We formulated four hypotheses related to the choice between parties in the set. All four were supported. We expected political values to contribute to the choice within the set, but suggested that value dimensions other than the ones that were decisive for the party set might be especially influential. Consider the example of the Labor Party and the Socialist Left Party set. Political ideology related to the authoritarian-libertarian and public-private dimensions are the main factors for including these two parties in the set. Hence, voters who consider these two parties have libertarian and leftist values. However, the environmental-economic growth dimension separates the ones who ended up voting for Social Left from the ones who chose Labor. While a voter's political value structure might make several parties acceptable, that structure also makes it more likely that they will choose one party within the set over the other. We also argued that the effect of political values would be closely related to perceptions of issue ownership. The results support this hypothesis. However, the explained variance increases considerably when issue ownership is introduced, and this indicates that issue ownership has a powerful independent effect on the choice between parties in the set.

Although the initial theory of issue ownership and previous research has focused on ownership of one particularly salient issue, we suggested that cumulative issue ownership might be equally important, particularly in a multidimensional, multiparty system like the Norwegian one. Political parties formulate and offer the voters comprehensive policy packages, and consequently issue ownership covering several issue areas, not just one salient issue, should be studied to a greater extent. The empirical results support this argument. Both singular and cumulative issue ownership had a significant effect on the decision in all four party sets studied here. However, the effect of salient Labor issue ownership was not significant in any of the models, and the effect of cumulative ownership was greater than the effect of salient single issue ownership in all analyses. Hence, our findings support the argument that voters take the totality of the party policies into consideration, and that issue ownership on several issues therefore is essential for parties. This notion needs to be further developed, both theoretically and empirically, in future research.

The basic argument put forward in this article is that voters' value structure renders voting for more than one party possible, particularly in multiparty systems. Moreover, the totality of issue ownership, more than salient singular ownership, seems to contribute to the choice between the parties included in the set. The elegant, parsimonious logic of the issue ownership model has thus been made more complex by these results. However, although the issue ownership theory may need to revised, the notion of party set and the reformulated issue ownership model increase our understanding of how stable and dynamic factors affect vote choice in multiparty systems.

\section{Acknowledgements}

We thank Elin Haugsgjerd Allern, Knut Heidar, Jo Saglie and two anonymous reviewers for constructive and helpful comments and suggestions. 


\section{Funding}

This work was supported by the Research Council of Norway.

\section{Notes}

1. Notable exceptions include van der Brug (2004), Belanger and Meguid (2008), Green and Hobolt (2008) and Martinsson (2009).

2. Party set is sometimes also referred to as consideration set.

3. However, the relative size of the latitudes varies in systematic ways (Sherif and Hovland, 1961). The size of the rejection-latitude increases when involvement increases. For example, voters who are proimmigration and feel strongly about the issue are more likely to reject parties that do not share the voters' policy position in the issue.

4. See Walgrave et al. (2012) for the associative dimension of issue ownership.

5. The model owes a great deal to research on agenda-setting and priming. Petrocik (1996) recognizes this and refers to Iyengar's work on priming as a foundation for his own work. According to agenda-setting theory, the issues that are important in the media over time will also become the issues that the public consider important (McCombs, 2004; McCombs and Shaw, 1972). By calling attention to some issues - to prime them - while ignoring others, the media influence the standards by which governments and politicians are judged (Iyengar and Kinder, 1987).

6. The combination of ownership and saliency is also emphasized by Belanger and Meguid (2008), but the fact that this is an essential part of Petrocik's initial model surprisingly seems to escape them.

7. In line with earlier research we use 'issue ownership' in the meaning 'most competent' on the micro level, although this term is less appropriate for the micro than the macro level.

8. In 1965 , only 15 per cent waited until the campaign. In 2005, the proportion had increased to 56 per cent.

\section{References}

Aardal, Bernt (ed.) (2011) Det politiske landskap. Oslo: Cappelen Damm Akademiske.

Bélanger, Éric and Bonnie M Meguid (2008) Issue Salience, issue ownership, and issue-based vote choice. Electoral Studies 27(3): 477-491.

Berglund, Frode (2004) Partiidentifikasjon og Politisk Endring. Oslo: Unipax.

Budge, Ian and Dennis J Farlie (1983) Explaining and Predicting Elections. London: George Allen \& Unwin.

Campbell, Angus, Philip E Converse, Warren E Miller, et al. (1960) The American Voter. Chicago, IL: University of Chicago Press.

Converse, Philip E (1964) The nature of belief systems in mass publics. In: David Apter (ed.) Ideology and Discontent. New York: Free Press, pp.206-261.

Dalton, Russel and Martin Wattenberg (eds) (2000) Parties without Partisans. Oxford: Oxford University Press.

Dalton, Russel, Scott Flanagan and Paul Allen Beck (1984) Electoral Change in Advanced Industrial Democracies. Realignment or Dealignment? Princeton, NJ: Princeton University Press.

Downs, Anthony (1957) An Economic Theory of Democracy. New York: Harper \& Brothers.

Flanagan, Scott C (1982) Changing values in advanced industrial societies. Inglehart's silent revolution from the åerspective of Japanese findings. Comparative Political Studies 14(4): 403-444.

Franklin, Mark, Tom Mackie and Henry Valen (1992) Electoral Change. Responses to Evolving Social and Attitudinal Structures in Western Countries. Cambridge: Cambridge University Press.

Franklin, Mark, Tom Mackie and Henry Valen (2009) Electoral Change. Responses to Evolving Social and Attitudinal Structures in Western Countries. Colchester: ECPR Press.

Green, Jane and Sara Hobolt (2008) Owning the issue agenda: Party strategies and vote choices in British politics. Electoral Studies 27(3): 460-476.

Holmberg, Sören and Henrik Oscarsson (2004) Väljare. Stockholm: Norstedts Juridik.

Inglehart, Ronald (1971) The silent revolution in Europe: Intergenerational change in post-industrial societies. American Political Science Review 65(4): 991-1017. 
Iyengar, Shanto and David Kinder (1987) News that Matters. Television and American Opinion. Chicago, IL: University of Chicago Press.

Karlsen, Rune (2004) Valgkamp i flerpartisystem - Aktualisering av saker og kamp om eierskap. Tidsskrift for samfunnsforskning 45(4): 611-635.

Knutsen, Oddbjørn (1995) Party choice. In: JW van Deth and Elisabeth Scarbrough (eds) The Impact of Values. Oxford: Oxford University Press, pp.160-196.

Knutsen, Oddbjørn and Staffan Kumlin (2005) Value orientations and party choice. In: Jacques Thomassen (ed.) The European Voter. Oxford: Oxford University Press, pp.125-166.

Lipset, Seymour M and Stein Rokkan (1967) Cleavage structures, party systems, and voter alignments: An introduction. In: Seymour M Lipset and Stein Rokkan (eds) Party Systems and Voter Alignments. New York: Free Press, pp.1-64.

Martinsson, Johan (2009) Economic Voting and Issue Ownership. An Integrative Approach. PhD dissertation. Gothenburg: Deptartment of Political Science, University of Gothenburg,

McCann, James A (1997) Electoral choices and core value change: The 1992 presidential campaign. American Journal of Political Science 41(2): 564-583.

McCombs, Maxwell (2004) Setting the Agenda. The Mass Media and Public Opinion. Cambridge: Polity Press.

McCombs, Maxwell and Donald L Shaw (1972) The agenda-setting function of mass media. Public Opinion Quarterly 36(2): 176-187.

Oscarsson, Henrik, Mikael Gilljam, and Donald Granberg (1997) 'The Concept of Party Set - A Viable Approach or Just Another Way to Cut the Same Cheese?', paper presented at the Annual Meeting of the Swedish Political Science Association, Uppsala, October 5-7.

Petrocik, John R (1996) Issue ownership in presidential elections, with a 1980 case study. American Journal of Political Science 40(3): 825-850.

Schwartz, Shalom H, Gian Vittorio Caprara and Michele Vecchione (2010) Basic personal values, core political values and voting: A longitudinal analysis. Political Psychology 31(3): 421-451.

Sherif, Muzafer and Carl I Hovland (1961) Social Judgement. New Haven, CT: Yale University Press.

Van der Brug, Wouter (2004) Issue ownership and party choice. Electoral Studies 23(2): 209-233.

Van der Brug, Wouter (2010) Structural and ideological voting in age cohorts. West European Politics 33(3): $586-607$.

Van der Brug, Wouter, Cees Van Der Eijk and Mark Franklin (2007) The Economy and the Vote: Economic Conditions and Elections in Fifteen Countries. Cambridge: Cambridge University Press.

van der Eijk, Cees (2002) Design issues in electoral research: taking care of (core) business. Electoral Studies 21(2): 189-206.

van der Eijk, Cees, Wouter Van Der Brug, Martin Kroh, et al. (2006) Rethinking the dependent variable in voting behavior: On the measurement and analysis of electoral utilities. Electoral Studies 25(3): 424-447.

Walgrave, Stefan, Jonas Lefevere and Anke Tresch (2012) The associative dimension of issue ownership. Public Opinion Quarterly. Epub ahead of print June 5. 2012. DOI:10.1093/poq/nfs023.

Walgrave, Stefan, Jonas Lefevere and Anke Tresch (2014) The limits of issue ownership dynamics: The constraining effect of party preference. Journal of Elections, Public Opinion and Parties 24(1): 1-19.

Walgrave, Stefan, Jonas Lefevere and Michiel Nuytemans (2009) Issue ownership stability and change: How parties claim and maintain issues through media appearances. Political Communication 26(2): 153-172.

Zaller, John R (1991) The Nature and Origins of Mass Opinion. Cambridge: Cambridge University Press.

\section{Author biographies}

Rune Karlsen is a Senior Research Fellow at the Institute for Social Research in Oslo, Norway. His interests include political communication, voting behaviour, political parties and political representation.

Bernt Aardal is Professor at the Department of Political Science, University of Oslo, a Research Professor at the Institute for Social Research in Oslo, and the Principal Investigator for the Norwegian Election Studies. His interests include voting behaviour, political participation and electoral systems. 